\title{
Yüksek Dayanımlı Betonla Üretilmiş Kirişlerde Plastik Mafsal Boyunun
}

\section{Belirlenmesi}

\author{
*1Yusuf Sümer \\ ${ }^{1}$ Sakarya Üniversitesi, Teknoloji Fakültesi, İnşaat Mühendisliği Bölümü, Sakarya, \\ ysumer@sakarya.edu.tr \\ Geliş Tarihi: 2017-03-09 Kabul Tarihi: 2017-06-30
}

\section{$\ddot{\mathbf{O z}}$}

Depremler sırasında betonarme yapılar elastik olmayan deformasyonlar yaparak yapıya gelen enerjiyi sönümlerler. Yapılarda bulunan eğilme elemanlarında oluşan plastik deformasyonlar plastik mafsal bölgesi olarak adlandırılan küçük bir bölgede oluşur ve bu bölge elemanın yük taşıma ve deformasyon kapasitesi için kritik öneme sahiptir. Statik itme (Pushover) yöntemi mevcut yapıların değerlendirilmesinde kullanılan doğrusal olmayan bir analiz yöntemidir. Bu yöntemde elemanların plastik mafsal özelliklerinin doğru tanımlanması çok önemlidir. Yapı elemanlarında oluşan plastik mafsal, yapı elemanlarının boyut ve malzeme özellikleriyle yakından ilgilidir. Plastik mafsal uzunluğunun belirlenmesinde günümüze kadar birçok deneysel çalışmalar yapılmış fakat eleman boyutlarının büyüklüğü, deneysel imkânların yetersizliği ve yapı elemanlarının kompozit malzeme özellikleri sebebiyle sınırlı bilgi edinilebilmiştir. Bu çalışmada sonlu elemanlar modeli kurularak ABAQUS yazılımı yardımıyla plastik mafsal boyu belirlenmeye çalışılmıştır. Literatürden elde edilen deneysel çalışmalar sonlu elemanlar modeliyle yük-deplasman ve şekil değiştirme kapasiteleri ile doğrulanmıştır. Plastik mafsal boyunun belirlenmesi için kiriş boyutları kiriş davranışını değiştirecek şekilde kısa, orta ve narin olarak değiştirilmiş, kiriş malzemesi de yüksek dayanımlı betona uygun olarak C50, C60 ve C80 olarak belirlenmiştir. Kirişlerde oluşan yenilme çatlakları ve donatı akma uzunlukları analiz edilerek her bir kiriş için plastik mafsal boyu belirlenmiş̧ir.

Anahtar kelimeler: Yüksek dayanımlı beton, Plastik mafsal boyu, Sonlu elemanlar analizi

\section{Determining Plastic Hinge Length of High Strength RC Beams}

\author{
*11Yusuf Sümer \\ ${ }^{1}$ Sakarya University, Faculty of Technology, Dept. Civil Engineering, Sakarya, \\ ysumer@sakarya.edu.tr \\ Received date: 2017-03-09 Accepted date: 2017-06-30
}

\begin{abstract}
During earthquake concrete structures dissipate energy by deforming inelastically. The plastic deformation localized in a small zone namely the plastic hinge zone is critical for flexural members as it governs the load carrying and deformation capacities of the member. Pushover analysis, one method of nonlinear static analysis, is generally used in the assessment of existing buildings. In pushover analysis nonlinear hinge properties of each member should be addressed. The formation of a plastic hinge in structural member depends on the structural member properties such as dimension. Due to the high non-linearity occurs in plastic hinge zone and restrictions by the time and cost especially in large tests, very limited knowledge has been obtained from the laboratory tests up to date. Moreover, past studies showed that none of the existing empirical models is adequate for prediction of plastic hinge length. This study tries to investigate the problem numerically using Nonlinear Finite Element Modeling (FEM) approach by employing software package ABAQUS. To achieve this, a numerical model is generated and verified with existing experimental studies obtained from the literature. Parametric studies are performed to investigate the plastic hinge length in terms of material properties concrete and dimensions of the member. High strength concrete is selected to be as C50, C60 and C80 and dimension of the beams are determined as deep, intermediate and slender. With the calibrated FEM model, the extent of concrete crushing zone and rebar yielding zone are examined to define the plastic hinge length of the member.
\end{abstract}

Keywords: High strength concrete, Plastic hinge length, Finite element analysis

Sorumlu yazar: Sakarya Üniversitesi, Teknoloji Fakültesi, İnşaat Mühendisliği, Sakarya, TÜRKIYE, 54187, ysumer@sakarya.edu.tr, Tel: 02642955454 


\section{Introduction}

Energy dissipation of reinforced concrete (RC) structures can be determined numerically by applying full-range analysis beyond plastic phase. In this analysis, yielding of reinforcement and crushing of concrete can be seen over a finite region known as plastic hinge length where the critical moment is present. Plastic hinge region of RC flexural members is a critical zone need to be given intensive care to prevent failure of structural members from extreme events such as earthquakes. There is no adequate determination of plastic hinge length of concrete structural elements. However, the length of plastic hinge region, $\mathrm{L}_{\mathrm{p}}$, is defined as the length over which the longitudinal reinforcement yields [1]. The performance of a plastic hinge is crucial to the load carrying and deformation capacities of flexural members of structures. The accuracy of the results obtained from nonlinear analysis is also directly related to the hinge definitions of the structure. Thus, plastic hinge length of RC members has been an interesting and complicated subject for researchers.

There are no definitive theoretical formulations to calculate plastic hinge length in the literature. Present calculations are based on empirical equations observed from tests [2-6]. Park and Paulay found that plastic hinge length of beams under monotonic loading is affected by concrete compressive strength, concrete ultimate strain, shear-span to depth ratio, and effective depth of section [7]. Mechanical properties of steel also affect $\mathrm{L}_{\mathrm{p}}$. Beeby studied the effects of the ratio of ultimate strength to yield strength of longitudinal reinforcement, $\mathrm{f}_{\mathrm{u}} / \mathrm{f}_{\mathrm{y}}$, and the ultimate strain, $\varepsilon_{\mathrm{u}}$ on plastic hinge length [8].

Limit state failure in flexure is achieved when continues increases in the external load reaches the capacity of the beam. If the designer proportion the beam to allow concrete and steel reach their capacity prior to failure, both materials will fail simultaneously at the limit state. Moreover, compression failure of concrete before the tension failure of steel should be avoided to confirm an adequate rotation capacity at limit state. This reserved rotation capacity will prevent brittle failure in case of overload or will cope with additional tensile forces created from different settlement of foundations, creep and shrinkage of concrete. Strain of tension reinforcement will be the determinant variable that defines the type of failure; tension controlled (ductile type of failure), compression controlled (brittle type of failure) and between. Thus, the amount of the tension reinforcement will determine the amount of strain and failure type of the beam. This behavior according to ACI 318-14 is illustrated in Figure 1a.

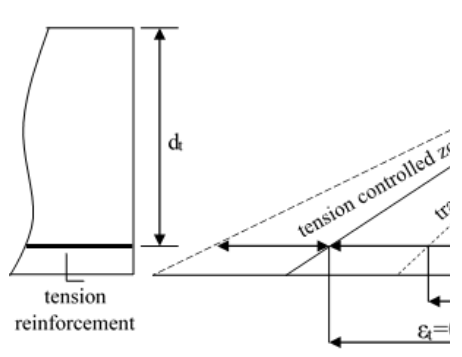

a) failure type of beams regarding to tensile strain of reinforcement, [9]

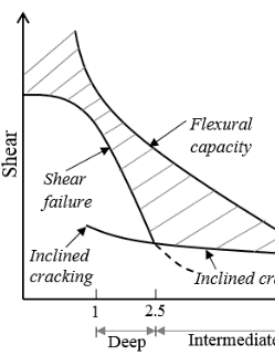

b) determination of beam slenderness,

[10]
Figure 1. Limit states of reinforced beam

The behavior of beam is also determined by the slenderness of the beam (Figure 1b). Slenderness of $\mathrm{RC}$ beam is defined as the ratio of its shear span $(\boldsymbol{a})$ to its depth $(\boldsymbol{d})$. Deep beam with $\boldsymbol{a} / \boldsymbol{d}$ from 1 to 2.5 will form few small cracks at mid-span but after the redistribution of internal forces bond failure between the tension reinforcement and surrounding concrete at support region follows. This is also known as shear compression failure. Intermediate beam with $\boldsymbol{a} / \boldsymbol{d}$ from 2.5 to 5.5 will fail at the inclined cracking load. Slender beam with $\boldsymbol{a} / \boldsymbol{d}$ greater than about 5.5 will fail in flexure prior to the formation of inclined cracks giving sufficient warning of the collapse of the beam. On the other hand, the compressive strength of the concrete has an influence on the rotation capacity of the beams [11-12]

In this paper, determination of $\boldsymbol{L}_{p}$ considering yielding zone of tension reinforcement is investigated for beams designed to achieve different types of failures. Verified nonlinear finite element approach is employed in the research to minimize time and cost for large test specimens. With the verified numerical model, the extent of reinforcement yielding zone to address the plastic hinge length is studied for RC beams with various failure modes.

\section{Development of Numerical Modeling}

Finite element analysis has been widely used in civil engineering applications from steel structure analysis to RC analysis. [13-14]. Nonlinear finite element software package, ABAQUS is employed to simulate experimental testing. Numerical model is verified with existing experimental data obtained from literature especially for load-deflection relation and axial force distribution of tensile steel reinforcement. The latter verification is more important since determination of $\mathrm{L}_{\mathrm{p}}$ in this study is 
made according to the yielding zone of tensile steel. Sensitivity of the numerical model against mesh density, dilation angle and fracture energy of concrete is also investigated.

Numerical model of simply supported beam under four-point loading is selected for verification purpose because it is the one obtained for both loaddeflection relation and axial force distribution at

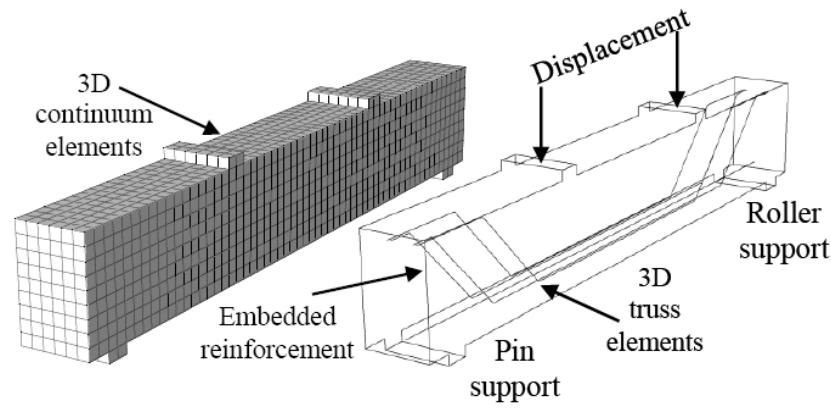

a) tensile steel are studied with three dimensional model. $3 \mathrm{~d}$ continuum elements and $3 \mathrm{~d}$ truss elements for concrete and steel reinforcement are used in finite element modeling, respectively. Shear dominant members are not modeled as individual finite members but their effects are included in concrete model by introducing confined concrete model. All the beams are loaded by displacement control in the vertical direction.

Figure 2. General layout of the beam used in verification models (a), beam used through parametric study (b)

Steel bars are merged into concrete elements by constraining the same degree of freedom at intersection joints of concrete and steel. Interface behavior between rebar and concrete is modeled by implementing tension stiffening effect into the concrete. (Figure 2a)

\subsection{Nonlinear Behavior of Materials}

Since the compression and tension stress-strain relation of the used materials are not reported in the test reports these relations are considered by using mathematical models from literature. Stress-strain curve of concrete under uniaxial compression is obtained by employing Hognestad parabola along with linear descending branch. Some modifications are made to this parabola according to CEB-FIP MC90 due to the effects of closed stirrups to catch the behavior of confined concrete [15].

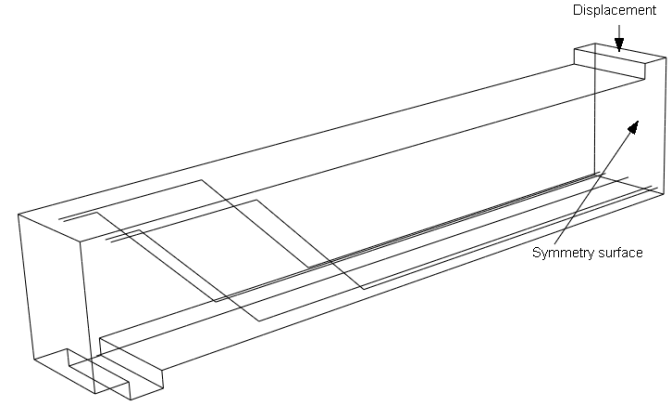

b)
Figure 3a displays a schematic representation of the uniaxial material response. In the figure, $\sigma$ is the compressive stress, $\mathbf{f}_{\mathbf{c u}}$ is the ultimate compressive stress, $\boldsymbol{\varepsilon}_{\mathbf{c}}^{*}$ is the peak compressive strain, $\mathbf{E}$ is the elastic modulus and $\mathbf{f}_{\mathbf{c}} *$ is the modified compressive strength. Bilinear model is adopted for tensile behavior of concrete as plotted in Figure 3b [16]. Crack opening, calculated as a ratio of the total external energy supply per unit area required to create a crack, is used to define the tensile behavior. Tensile fracture energy of concrete, $\left(\mathbf{G}_{\mathbf{F}}\right)$, is determined as a function of concrete compressive strength, $\mathbf{f}_{\mathbf{c}} *$, and a coefficient, $\mathbf{G}_{\mathbf{f o}}$, which is related to the maximum aggregate size [17]. Yield surface of concrete considering both tension and compression is given in Figure 3c. Dilation angle, mesh sensitivity and appropriate aggregate size for the concrete models are effective parameter for the numerical analysis and searched carefully in every verified model.

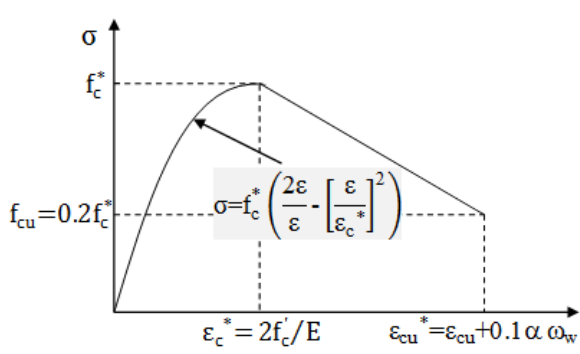

a) Hognestad concrete compressive behavior

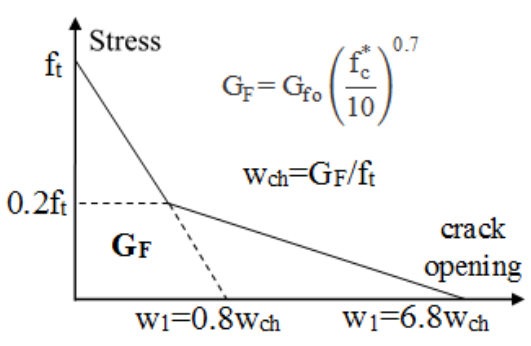

b) Bilinear tensile behavior

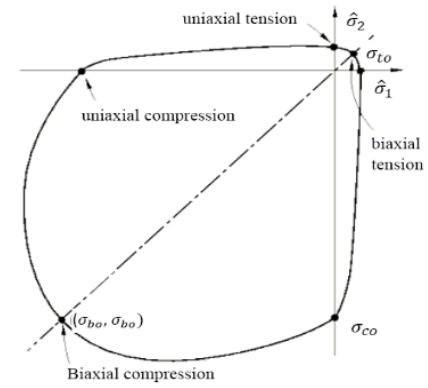

c) Biaxial yield surface of concrete, [18]

Figure 3. Material models and yield surface of concrete

Sorumlu yazar: Sakarya Üniversitesi, Teknoloji Fakültesi, İnşaat Mühendisliği, Sakarya, TÜRKIYYE, 54187, ysumer@sakarya.edu.tr, Tel: 02642955454 
Concrete Damaged Plasticity (CDP) model combining the effect of both damage and plasticity is used in this study. Tensile and compressive response of concrete including damage parameter is given in Figure 4. In this study damage variable in compression is calculated by using the equations given in Figure 4a [19]. The parameter $\mathbf{b}_{\mathbf{c}}$ represents the relation between plastic and inelastic strains and can be determined using curve-fitting of cyclic tests

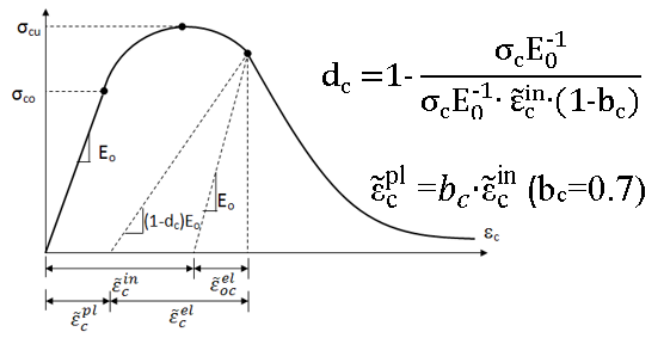

a) CDP model of concrete in compression
[20]. Damage variable in tension is determined from bilinear behavior of concrete and values are plotted in Figure 4b.

$$
\begin{aligned}
& \sigma_{\mathrm{t}}=\left(1-\mathrm{d}_{\mathrm{t}}\right) \cdot \mathrm{E}_{0} \cdot\left(\varepsilon_{\mathrm{t}}-\varepsilon_{\mathrm{t}}^{\sim \mathrm{pl}}\right) \\
& \sigma_{\mathrm{c}}=\left(1-\mathrm{d}_{\mathrm{c}}\right) \cdot \mathrm{E}_{0} \cdot\left(\varepsilon_{\mathrm{c}}-\varepsilon_{\mathrm{c}}^{\sim \mathrm{pl}}\right)
\end{aligned}
$$
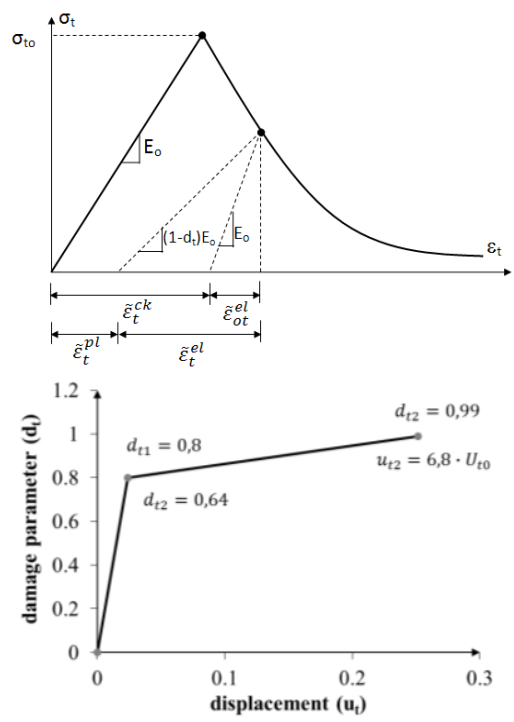

b) CDP model of concrete in tension

Figure 4. Concrete damage plasticity model [18]

Experimentally determined mechanical response values from coupon testing appear in Figure 5 converted to an idealized multi-linear true stress and logarithmic strain format using the given equations.

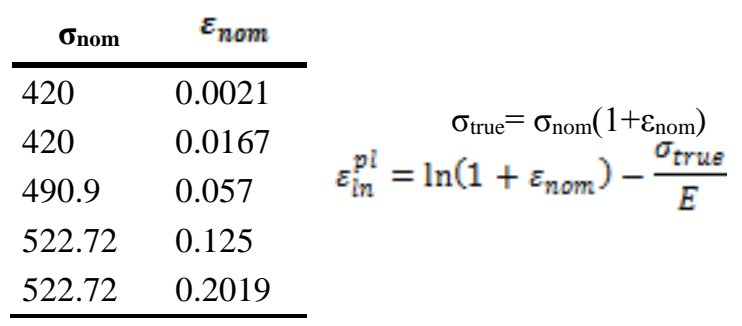

\begin{tabular}{ll}
\multicolumn{1}{c}{ бtrue } & \multicolumn{1}{c}{$\varepsilon_{l n}^{p l}$} \\
\hline 420.89 & 0 \\
427 & 0.0144 \\
519.22 & 0.0535 \\
588.06 & 0.1148 \\
628.27 & 0.1807 \\
\hline
\end{tabular}

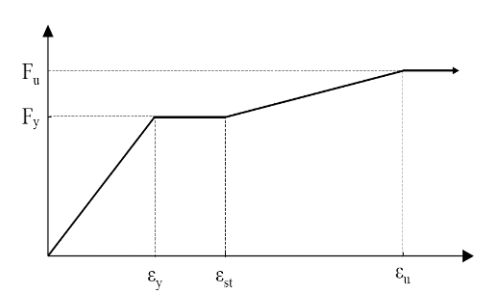

Figure 5. Material model for reinforcement steel [21]

\section{Numerical Model Verification}

Since determination of yielding zone of reinforcement steel is at the heart of this study the ability of numerical model addressing the yielding zone of reinforcement steel must be verified with the existing test results so that further parametric studies can be made with the proposed numerical model.

However, measuring the state of stress at the reinforcement is rather difficult due the surrounding concrete. Thus, very limited data is available at the literature. To have satisfying verification, test specimens constructed with a technique of installing strain gages through the center of the reinforcement by Mainst, 1952 is selected for this study. Herein it is called Test case 3 and it is used to verify the ability of the numerical model to simulate the yielding of tensile reinforcement of $\mathrm{RC}$ beam.

Load-displacement relation is also important data to check whether the proposed model identify the rigidity of the experimental test specimen.

Three experiments are selected for verification purposes. Test case 1 and 2 are used to show the 
robustness of the model to simulate the loaddeflection relationship. Details of these two experiments can be found from Arduini et al., 1997,
Sharif et al., 1994, respectively. Finally, layout of experimental specimens are plotted in Figure. 6 and material properties are listed in Table 1.

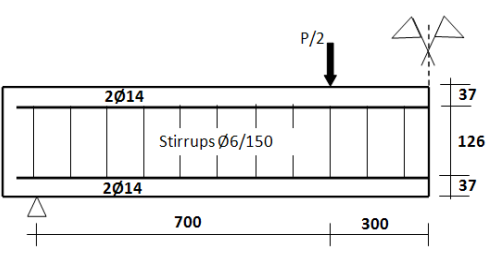

Test case-1 [22]

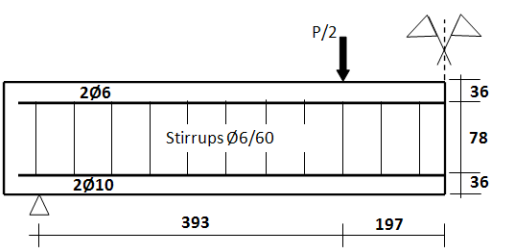

Test case-2 [23]

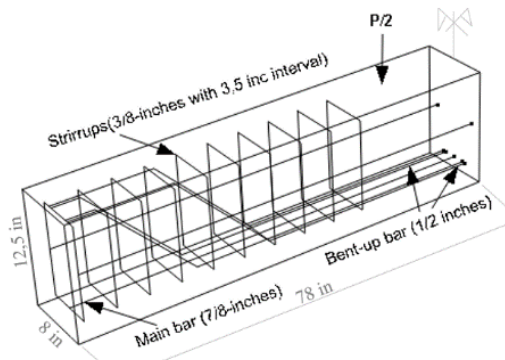

Test case-3 [24]

Figure 6. Layout of test beam (dimensions are $\mathrm{mm}$ in Test case-1 and 2)

When the verification results given in Figure $7 \mathrm{a}$ are examined, it is concluded that proposed numerical modeling approach can successfully represent the experimental results. The stress distribution at tensile steel (main bar) for different load levels are compared from both experiment and numerical model in Figure $7 \mathrm{~b}$. The difference where stress vary rapidly is believed to be the result of crack propagation which is not considered in numerical model. Other than that overall pattern of the diagrams agrees well.

Table 1. Material properties of test beams.

\begin{tabular}{ccccccccc}
\hline $\begin{array}{c}\text { Test } \\
\text { Case }\end{array}$ & $\begin{array}{c}\text { Beam } \\
\text { Ref.No }\end{array}$ & $\begin{array}{c}\mathbf{E}_{\mathbf{c}} \\
(\mathbf{G P a})\end{array}$ & $\begin{array}{c}\mathbf{f}_{\mathbf{c}} \\
(\mathbf{M P a})\end{array}$ & $\begin{array}{c}\mathbf{f}_{\mathbf{t}} \\
(\mathbf{M P a})\end{array}$ & $\begin{array}{c}\mathbf{E}_{\mathbf{s}} \\
(\mathbf{G P a})\end{array}$ & $\begin{array}{c}\mathbf{f}_{\mathbf{y}} \\
(\mathbf{M P a})\end{array}$ & $\begin{array}{c}\text { Tension } \\
\text { Bars (mm) }\end{array}$ & $\begin{array}{c}\text { Bent-up } \\
\text { bars (mm) }\end{array}$ \\
\hline 1 & A1 & 25 & 33 & 2.6 & 200 & 540 & $2 \Phi 14$ & - \\
2 & P1 & 27 & 37.7 & - & 200 & 450 & $2 \Phi 10$ & - \\
3 & B15 & 26.8 & 28.8 & 2.84 & 213.7 & 5943 & $1 \times 22.2$ & $4 \times 12.72$ \\
\hline
\end{tabular}

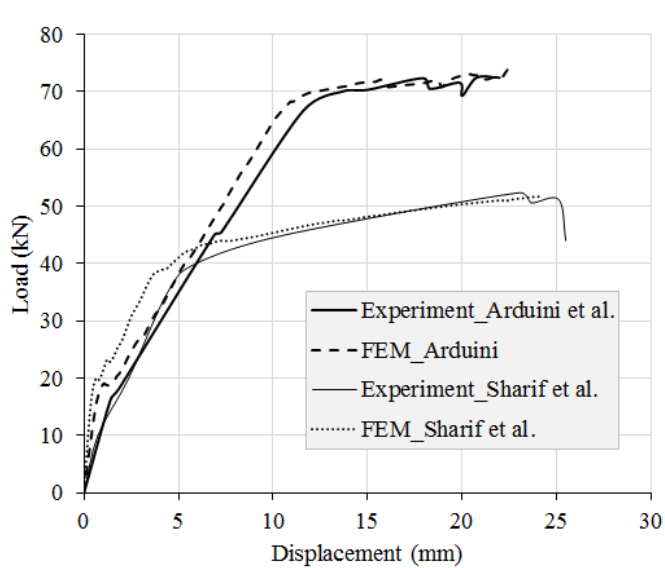

a) Load-deflection relationship obtained by using $35^{\circ}$ and $30^{\circ}$ dilation angle, 50 and $25 \mathrm{~mm}$ mesh size and 16 $8 \mathrm{~mm}$ aggregate size respectively.

Figure 7. - Numerical model verification results
All these plots show that finite element modeling techniques applied herein, are valid for RC beams. Load deflection relation and stress distributions of individual element could be monitored very well. Based on these results, it appears that the present modeling techniques are sufficiently robust to undertake the further parametric study to investigate the effects of different parameters on plastic hinge

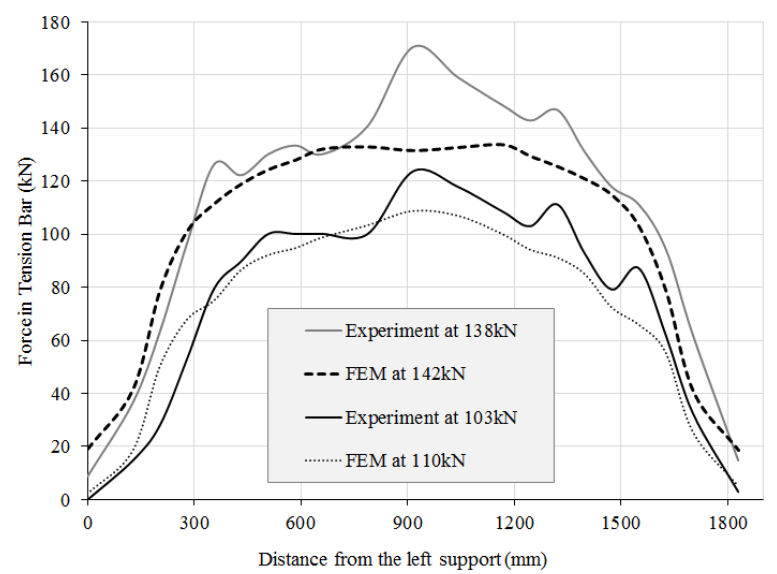

b) Stresses at tension reinforcement of RC beam obtained by using $30^{\circ}$ dilation angle, $35 \mathrm{~mm}$ mesh and $16 \mathrm{~mm}$ aggregate size

regions of existing $\mathrm{RC}$ beams. Therefore performance of a plastic hinge and load carrying and deformation capacities of flexural members will be determined easily by the numerical studies.

\section{Parametric Study}

A parametric study using the aforesaid finite element

Sorumlu yazar: Sakarya Üniversitesi, Teknoloji Fakültesi, İnşaat Mühendisliği, Sakarya, TÜRKIYYE, 54187 , ysumer@sakarya.edu.tr, Tel: 02642955454 
modelling techniques was carried out to investigate the effect of tensile yielding on the $\mathrm{L}_{\mathrm{p}}$ of reinforced concrete beams designed to achieve different failure mode (Table 2). Half of the beam is modelled (see Fig. 2b) with three different lengths to consider the slenderness effect and with three different tension reinforcement steel ratio to consider the ductile behavior. The nomination $\mathrm{S}, \mathrm{I}$ and $\mathrm{D}$ represents the slenderness of beam stating, Slender, Intermediate and Deep as described according to Figure 1. All the beams are designed with steel ratio to be in transition zone with a value of $\varepsilon_{t}=0.004$.

Table 2. Parametric study for numerical beams to achieve different flexural behavior

\begin{tabular}{ccccc}
\cline { 3 - 5 } & & \multicolumn{3}{c}{ Slenderness } \\
\cline { 3 - 5 } & & Deep (D) & Intermediate (I) & Slender (S) \\
\hline \multirow{2}{*}{ Concrete } & C50 & Beam C50D & Beam C50I & Beam C50S \\
Class & C60 & Beam C60D & Beam C60I & Beam C60S \\
& C80 & Beam C80D & Beam C80I & Beam C80S \\
\hline
\end{tabular}

Geometry and material properties of test beams are presented in Table 3. The beams are loaded by displacement control until they fail. The length of loading span is taken as equal to the shear span, $\boldsymbol{a}$.
So the total length of the beam is $3 a$. For the credence of the study, beams reinforcement scheme is applied identical with the Test case- 3 used in the verification study.

Table 3. Mechanical and geometrical variables of numerical beams used in parametric studies.

\begin{tabular}{|c|c|c|c|c|c|c|c|c|c|c|c|}
\hline $\begin{array}{l}\text { Specimen } \\
\text { Name }\end{array}$ & $\begin{array}{c}\text { Et (strain of } \\
\text { steel) }\end{array}$ & $\begin{array}{c}\rho(\text { reinforcement } \\
\text { ratio })\end{array}$ & a, $\mathbf{m m}$ & $\begin{array}{c}\mathbf{L}, \\
\mathbf{m m}\end{array}$ & $a / d$ & $\mathbf{L} / \mathbf{h}$ & $\begin{array}{c}\mathbf{f c}, \\
\mathbf{M P a}\end{array}$ & $\begin{array}{c}\mathbf{f t}, \\
\mathbf{M P a}\end{array}$ & $\begin{array}{c}\text { Ec, } \\
\text { GPa }\end{array}$ & $\begin{array}{c}\mathbf{f y}, \\
\text { MPa }\end{array}$ & $\begin{array}{c}\mathbf{E}_{\mathrm{s}}, \\
\mathbf{G P a}\end{array}$ \\
\hline C50S & $\varepsilon_{\mathrm{t}}=0.004$ & 0.0184 & 2000 & 6200 & 5.7 & 15.5 & 50 & 4.24 & 33.2 & 420 & 210 \\
\hline C60S & $\varepsilon_{\mathrm{t}}=0.004$ & 0.0184 & 2000 & 6200 & 5.7 & 15.5 & 60 & 4.65 & 36.4 & 420 & 210 \\
\hline C80S & $\varepsilon_{t}=0.004$ & 0.0184 & 2000 & 6200 & 5.7 & 15.5 & 80 & 5.36 & 42.0 & 420 & 210 \\
\hline C50I & $\varepsilon_{\mathrm{t}}=0.004$ & 0.0184 & 1400 & 4500 & 4 & 11.25 & 50 & 4.24 & 33.2 & 420 & 210 \\
\hline C60I & $\varepsilon_{t}=0.004$ & 0.0184 & 1400 & 4500 & 4 & 11.25 & 60 & 4.65 & 36.4 & 420 & 210 \\
\hline C80I & $\varepsilon_{\mathrm{t}}=0.004$ & 0.0184 & 1400 & 4500 & 4 & 11.25 & 80 & 5.36 & 42.0 & 420 & 210 \\
\hline C50D & $\varepsilon_{\mathrm{t}}=0.004$ & 0.0184 & 700 & 2400 & 2 & 6 & 50 & 4.24 & 33.2 & 420 & 210 \\
\hline C60D & $\varepsilon_{\mathrm{t}}=0.004$ & 0.0184 & 700 & 2400 & 2 & 6 & 60 & 4.65 & 36.4 & 420 & 210 \\
\hline C80D & $\varepsilon_{\mathrm{t}}=0.004$ & 0.0184 & 700 & 2400 & 2 & 6 & 80 & 5.36 & 42.0 & 420 & 210 \\
\hline
\end{tabular}

\section{Results and Discussions}

Once the analysis is completed stress level at tension bar is investigated closely. Initiation and propagation of yielding for each loading step is checked until ultimate load point is reached. Stress level of tension bar is plotted at ultimate load level to determine the yielding zone of reinforcement. Moreover, cracks at concrete are also plotted for the same load level to address the plastic hinge length. These plots are given in Figure 8. Considering the length of yield line of tension bar and concrete cracks, $\mathrm{L}_{\mathrm{p}}$ is calculated and normalized with the effective depth of the cross section, $\mathrm{d}$ (Table 4 ). 

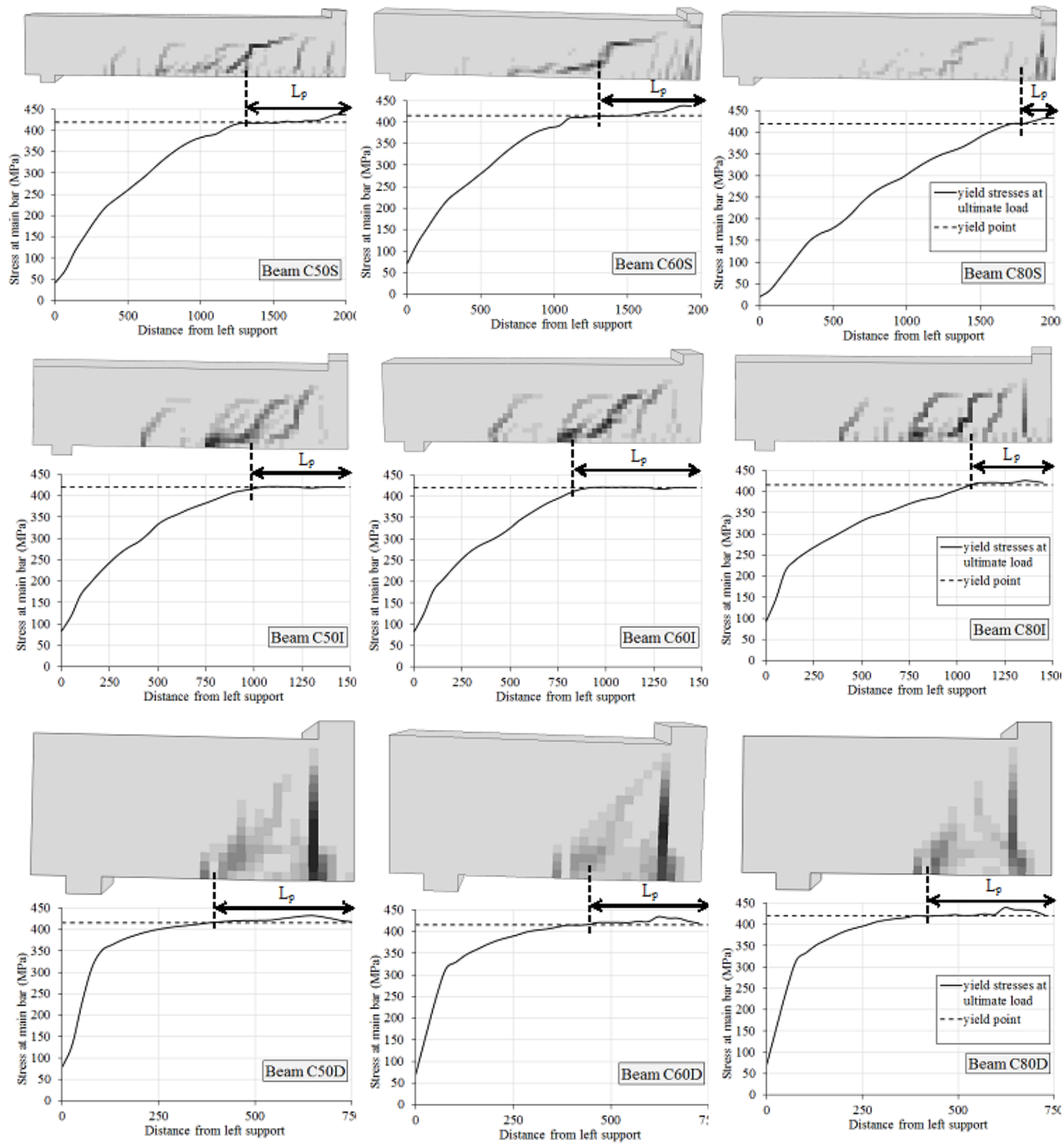

Figure 8. Determination of $L_{p}$ for each parametric beam

Table 4. Values of $L_{p}$ for each parametric beam

\section{Slenderness}

\begin{tabular}{llcccccc}
\cline { 3 - 7 } & & \multicolumn{2}{c}{ Deep $(\mathrm{D})$} & \multicolumn{2}{c}{ Intermediate $(\mathrm{I})$} & \multicolumn{2}{c}{ Slender $(\mathrm{S})$} \\
\hline \multirow{4}{*}{ Concrete } & & $\mathrm{L}_{\mathrm{p}}(\mathrm{mm})$ & $\mathrm{L}_{\mathrm{p}} / \mathrm{d}$ & $\mathrm{L}_{\mathrm{p}}(\mathrm{mm})$ & $\mathrm{L}_{\mathrm{p}} / \mathrm{d}$ & $\mathrm{L}_{\mathrm{p}}(\mathrm{mm})$ & $\mathrm{L}_{\mathrm{p}} / \mathrm{d}$ \\
\cline { 3 - 8 } Class & $\mathrm{C} 50$ & 0.99 & 495 & 1.32 & 740 & 1.97 \\
& $\mathrm{C} 60$ & 310 & 0.83 & 535 & 1.43 & 755 & 2.01 \\
& $\mathrm{C} 80$ & 303 & 0.81 & 481 & 1.28 & 357 & 0.95 \\
\hline
\end{tabular}

For a given steel ratio (presented in Table 3), $\mathrm{L}_{\mathrm{p}} / \mathrm{d}$ value increases as the slenderness ratio increases. On the other hand, in deep beams, $\mathrm{L}_{\mathrm{p}} / \mathrm{d}$ value decreases as the concrete class increases. The highest value of $\mathrm{L}_{\mathrm{p}} / \mathrm{d}$ is obtained as 2.01 for slender beam reinforced with $\mathrm{C} 60$ concrete class. The minimum value of $\mathrm{L}_{\mathrm{p}} / \mathrm{d}$ is obtained as 0.80 for deep beam reinforced with C80 concrete class. $\mathrm{L}_{\mathrm{p}} / \mathrm{d}$ value is decreased by up to $48 \%$ for the biggest concrete class used in this study for slender beams with same shear span. However, 
the decreasing ratio changed $11 \%$ and $19 \%$ in intermediate and deep beams respectively. On the other hand, maximum $L_{p}$ values are observed when the $\mathrm{C} 60$ concrete class were used in intermediate and slender beams. All the deep beams have the least $\mathrm{L}_{\mathrm{p}}$ value while the slender beams have the maximum $L_{p}$ values.

For the comparison, some of the most known expressions in the literature for determining the equivalent plastic hinge length used to calculate $\mathrm{L}_{\mathrm{p}}$ for the beams are tabulated in Table 5. Results showed that in terms of $\mathrm{L}_{\mathrm{p}}$, standard deviations are substantially increases from deep beams to the slender beams. However, when the concrete class is increases the standard deviations are decreases in each group. The closer results are determined with the Panagiotakos and Fardis expressions for the Intermediate and Deep beams.

Table 5. Comparison of $\mathrm{L}_{\mathrm{p}}$ from literature (units are in $\mathrm{mm}$ )

\begin{tabular}{lcccccc}
\hline $\begin{array}{l}\text { Beam } \\
\text { Name }\end{array}$ & $\begin{array}{c}\text { FEM } \\
\text { results }\end{array}$ & Corley & Mattock & $\begin{array}{c}\text { Paulay } \\
\text { and } \\
\text { Priestley }\end{array}$ & $\begin{array}{c}\text { Panagiotakos } \\
\text { and Fardis }\end{array}$ & $\begin{array}{c}\text { Standart } \\
\text { Deviations }\end{array}$ \\
\hline C50 Slender & 740 & 212 & 290 & 453 & 527 & 185,54 \\
\hline C60 Slender & 755 & 212 & 290 & 453 & 527 & 190,35 \\
\hline C80 Slender & 357 & 212 & 290 & 453 & 527 & 112,29 \\
\hline C50 Intermediate & 495 & 206 & 263 & 297 & 428 & 107,22 \\
C60 Intermediate & 535 & 206 & 263 & 297 & 428 & 119,44 \\
C80 Intermediate & 481 & 206 & 263 & 297 & 428 & 103,18 \\
\hline C50 Deep & 372 & 199 & 228 & 241 & 302 & 61,74 \\
C60 Deep & 310 & 199 & 228 & 241 & 302 & 43,10 \\
C80 Deep & 303 & 199 & 228 & 241 & 302 & 41,40 \\
\hline
\end{tabular}

\section{CONCLUSIONS}

Modelling of plastic hinges is quite important since in RC structure analysis dissipation of energy is achieved through these hinges. There are several expressions in literature that defines the location of plastic hinges either by considering yielding of tension steel or contraflexure or both. However, existing experiments in the literature proved that shear span to depth ratio is also very important on the definition of plastic hinge length. In this numerically verified study RC beams with different failure modes are created by considering shear span to depth ratio. Otherwise, special attention was paid to high strength concrete. Then plastic hinge length for these beams are determined. Findings are summarized as follows:

- Finite element approach is capable of capturing load-deflection relationship and

\section{KAYNAKLAR}

[1] Fenwick, R.C., Thom, C.W., Shear deformation in reinforced concrete beams subjected to inelastic cyclic loading. Research Report No: stresses developed in the steel bar embedded in concrete.

- $\mathrm{L}_{\mathrm{p}}$ is correlated with the shear span to depth ratio value which is named as slender, deep and intermediate beam in this study.

- As the reinforced concrete class increases plastic hinge length decreases independent from slenderness.

- Results calculated with formulas from the literature are very divergent estimating the hinge length of a high strength RC beams.

- The Panagiotakos and Fardis formula give reliable estimates of hinge length for the high strength concrete elements constructed as Deep beams.

- More analysis and experimental results is required to confirm these observations for the high strength concrete.

279, Department of Civil Engineering, University of Auckland, 1982.

[2] Corley, G.W., Rotation capacity of reinforced concrete beams. ASCE J Struct Div. 1966; 121:146-92. 
[3] Mattock, A.H., Discussion of rotational capacity of reinforced concrete beams by W. D. G. Corley. ASCE J Struct Div. 1967; 519:522-93.

[4] Priestley, M.J.N. and Park, R., Strength and ductility of concrete bridge columns under seismic loading. ACI Struct J. 1987; 61:76-84.

[5] Panagiotakos, T.B. and Fardis, M.N., Deformations of reinforced concrete members at yielding and ultimate. ACI Struct J. 2001; 135:48-98.

[6] Federal Emergency Management Agency. FEMA 356 Prestandart and Commentary for the Seismic Rehabilitation of Buildings. Washington DC, 2000.

[7] Park, R. and Paulay, T., Reinforced Concrete Structures. John Wiley \& Sons, New York, 1975.

[8] Beeby, A.W., Ductility in reinforced concrete: why is it needed and how is it achieved. Structural Engineer. 1997; 311:318-75 (18).

[9] American Concrete Institute. Building Code Requirements for Structural Concrete, ACI 31814, ACI, Detroit, MI, 2014.

[10] Wight, J.K., Macgregor JG. Reinforced Concrete Mechanics and Design, $5^{\text {th }}$ Edition, 2012.

[11]Lopes, S.M.R. and Bernardo, L.F.A., Plastic rotation capacity of high-srength concrete beams. Materials and Structures. 2003; 22-31 (36).

[12] Mendis, P., Plastic Hinge Length of Normal and high Strength concrete in Flexure. Advances of Structural Engineering, 2001; vol.4, no:4.

[13] Potisuk, T., Higgins, C.C., Miller, T.H., and Yim, S,C., Finite Element Analysis of Reinforced Concrete Beams with Corrosion Subjected to Shear. Advances in Civil Engineering, vol. 2011, Article ID 706803, doi:10.1155/2011/706803, 2011.

Agcakoca, E., Aktas, M., The Impact of the HMCFRP Ratio on the Strengthening of Steel Composite I-Beams. Mathematical Problems in Engineering, vol. 2012, Article ID 183906, doi:10.1155/2012/183906, 2012.

[14] Arduini, M., Nanni, A., Behavior of precracked RC beams strengthened with carbon FRP sheets. ASCE, Journal of Composites for Construction 1997; 63-70-1 (2).

[15] Coronado, A.C. and Lopez, M.M., Sensitivity analysis of reinforced concrete beams strengthened with FRP laminates. Cement and Concrete Composites 2006; 102:114-28 (1).

[16] CEB-FIP MC90. Comite Euro-International du Beton, CEB-FIP Model Code 1990, Bulletin D’Information, No: 215, Lausanne, 1993.
[17] ABAQUS. Theory Manual, Version 6.13, Hibbit, Karlsson \& Sorensen, Inc., Pawtucket, Rhode Island, USA.

[18] KAMALI, A.Z., Shear strength of reinforced concrete beams subjected to blast loading. Master of Science Thesis, Stockholm, Sweden, 2012.

[19] Sinha, B.P., Gerstle, K.H., Tulin, L.G., Stressstrain relations for concrete under cyclic loading. ACI Journal 1964; 195:211-61.

[20] Aktas, M. and Earls, C.J., Minor axis momentthrust response behavior in steel I-shaped members. Journal of Structural EngineeringASCE 2006; 1079:1086-132.

[21] Arduini, M.D.T. and Nanni, A., Brittle failure in FRP plate and sheet bonded beams. ACI Structural Journal 1997; 363:370-94 (4).

[22] Sharif, A., Al-Sulaimani, G.J., Basunbul, I.A., Baluch, M.H., Ghaleb, B.N., Strengthening of initially loaded reinforced concrete beams using FRP plates. Struct J (ACI) 1994; 160:166-91 (2).

[23] Mains, R.M., Measurement of the distribution of tensile and bond stresses along reinforcing bars. Journal of the American Concrete Institute, Proceedings 1951; 225:252-48 (3). 